\title{
Simulating the effect of the North Atlantic Oscillation on frost injury in winter wheat
}

\author{
Tomas Persson $^{1, *}$, Anne Kari Bergjord ${ }^{2}$, Mats Höglind ${ }^{1}$ \\ Norwegian Institute for Agricultural and Environmental Research, Grassland and Landscape Division, ${ }^{14353}$ Klepp Stasjon, \\ Norway, and ${ }^{2} 7500$ Stjørdal, Norway
}

\begin{abstract}
Climate and weather variability affect agricultural crop production. The North Atlantic Oscillation (NAO) is the variation in air pressure difference in the northern Atlantic Ocean. A positive NAO index with higher than normal air pressure near the Azores and lower than normal near Iceland results in warm and wet winters in northwestern Europe. A negative NAO index gives opposite climatic effects in this region. We determined the effect of the NAO on the risk of frost injury in winter wheat for conditions that represent northwestern Europe by applying the FROSTOL model to dynamically simulate hardening, de-hardening and other physiological processes determining frost tolerance and frost injury in winter wheat. This model uses soil surface temperature and snow cover as driving variables. In total, 53 winter seasons from 1957-58 to 2009-10 were simulated to account for historical trends and variations in the NAO. Monthly and seasonal mean NAO indices for all years within this period were categorised into positive, neutral or negative phases. The winter wheat simulations included 3 locations in Norway (Apelsvoll, Ås and Kvithamar), 2 wheat frost tolerance types and 3 planting dates. The results showed that negative NAO phases, especially in February and March, increased the risk of frost injury in winter wheat. The risk of frost injury was higher at Apelsvoll and Ås than at Kvithamar, especially in negative NAO phases or after early planting. The results obtained can be used to design crop management practices and systems with higher production security.
\end{abstract}

KEY WORDS: NAO - Frost tolerance - Production risk - Climate variability - Winter cereals · Yield security

Resale or republication not permitted without written consent of the publisher

\section{INTRODUCTION}

Climate and weather variability affect the production and yield security of agricultural field crops throughout the world (Schmidhuber \& Tubiello 2007). In wheat production, there is a significant variation in grain yield between years and geographical regions due to weather and climate factors (Hsieh et al. 1999, Izaurralde et al. 1999, Alexandrov \& Hoogenboom 2001, Cantelaube et al. 2004). Winter wheat is an economically important crop in northern Europe (Statistics Sweden 2011, Matilda Agricultural Statistics 2012), including Norway (Rognstad \& Steinset 2010). Major constraints to winter wheat production in northern Europe and other coldtemperate climate regions, e.g. Canada and the northern USA, are the risk of winter kill due to low temperature (Skinner \& Mackey 2009, Bergjord et al. 2010), other winter stress factors such as ice encasement (Hakala et al. 2011) and fungal infections (Iriki et al. 2001, Matsumoto 2009). There is considerable variability in climate and weather conditions over time and space in northwestern Europe (HansenBauer et al. 2009), and this imposes an uncertainty in winter survival and thus also in the predicted yield of winter wheat. Further knowledge about how climate and weather variability affects frost injury in winter wheat could decrease this uncertainty. Specifically, 
the identification of possible trends or patterns in climate variability that determine the frost injury rate of winter wheat could help production planning and increase the yield security of this crop.

The North Atlantic Oscillation (NAO) is a welldocumented atmospheric phenomenon that affects climate conditions in the northern hemisphere, including Europe and eastern North America (Hurrell et al. 2003). In fact, in many geographical regions the NAO is one of the principal influences on climate - including air temperature, precipitation and storm activity (Dickson et al. 2000, Trigo et al. 2002) — and thus has considerable indirect effects on different sectors in society. The NAO index is defined as the difference in surface air pressure between a region with its centre around the Azores (alternative centres near Lisbon or Gibraltar are sometimes used) and another region near Iceland. It is thus a measure of the redistribution of atmospheric mass (Bojariu \& Gimeno 2003, Hurrell et al. 2003). A positive NAO index refers to a higher than normal air pressure at the Azores and a lower than normal air pressure at Iceland. The opposite situation results in a negative NAO index (Hurrell et al. 2003). The effect of the NAO on climate conditions varies considerably among geographic regions. For example, in northwestern Europe, a positive NAO index is associated with winters that are milder and wetter than normal (Hurrell et al. 2003). A negative NAO index has the opposite effects on the climate in this region. Across different exposed sectors of society, the adaptability to NAO is strongly related to its predictability (Bojariu \& Gimeno 2003, Hurrell et al. 2003). Currently, methods to predict winter NAO based on climatic conditions several months in advance are being developed. Approaches to predict the winter season NAO index include methods based on forcing factors influencing the atmospheric conditions (Bojariu \& Gimeno 2003), including sea surface temperature up to 6 mo in advance (Bojariu \& Gimeno 2003, Rodwell \& Folland 2003), sea ice conditions and autumn Eurasian snow cover (Bojariu \& Gimeno 2003), and eruptions of tropical volcanoes (Fischer et al. 2007). However, the predictability of winter NAO is still rather low, due to incomplete understanding of the physical components that underlie the relations between the above-mentioned factors and the winter NAO (Cohen \& Fletcher 2007).

The NAO has a significant effect on the agricultural sector, for example on the grain yield of wheat (Gimeno et al. 2002, Cantelaube et al. 2004, Rodriguez-Puebla et al. 2007) and rye (Gimeno et al. 2002), and on the grain quality of wheat (Atkin- son et al. 2005, Atkinson et al. 2008). The NAO also affects non-cereal crops, such as lemons and olives in southern Europe (Gimeno et al. 2002). However, while the effect of NAO on the yield of cereals and other agricultural crops is well documented, there is very little or no published information about its possible effect on winter survival of wheat and other cereal crops. Increased knowledge about interannual patterns in winter wheat survival due to NAOrelated climate variability would be useful for predicting and increasing winter wheat production potential and security in northern Europe. For example, such information could help evaluate and design production systems for winter wheat in regions where there is currently little or no production of this crop due to unfavourable winter conditions during certain years.

Simulation models enable different aspects of crop production to be evaluated over long time periods and large geographical regions (Hoogenboom et al. 2004), which is rarely possible with field trials due to high economic costs or other practical constraints. The literature includes a few examples of weather-driven models, which enable the hardening and frost tolerance of winter wheat to be simulated as a function of environmental factors such as soil temperature, precipitation, snow cover and soil frost depth (Ritchie 1991, Savdie et al. 1991, Fowler et al. 1999, Bergjord et al. 2008). One frost tolerance model was initially developed and applied to conditions representing Canada (Fowler et al. 1999). This model simulates the hardening and de-hardening of winter wheat to obtain a range of values for LT50, i.e. the temperature at which $50 \%$ of the plants die. A refined version of this model, called FROSTOL, has been developed for evaluation of winter wheat survival in Norway (Bergjord et al. 2008) and other regions in northern Europe (Bergjord et al. 2010). The FROSTOL model can also be applied to determine the effect of NAO on winter wheat hardening and winter survival and to identify management practices, e.g. planting date, that decrease the negative effect of NAO on winter wheat survival.

The overall goal of the present study was to determine the effect of the NAO on the risk of frost injury in winter wheat. Specifically, the FROSTOL model was applied to determine the effect of the NAO on frost risk at soil surface temperatures below the simulated LT50 of winter wheat for a range of conditions that represent (1) 3 different geographical regions in Norway, (2) 2 frost-tolerance types of wheat and (3) 3 different planting dates. 


\section{MATERIALS AND METHODS}

\subsection{North Atlantic Oscillation index}

Data on the monthly mean NAO index for winter months in the period 1950-2010 were obtained from the Climate Prediction Center of the National Oceanic and Atmospheric Administration (NOAA) (www.cpc.ncep.noaa.gov/products/precip/CWlink/ pna/nao.shtml). During this period, the winter season NAO index varied considerably (Fig. 1). A division into positive, negative or neutral NAO phases was performed according to Gimeno et al. (2002) and Lopez-Moreno \& Vicente-Serrano (2008). A positive or negative phase was defined as a year or month when the NAO index was more than one standard deviation higher or lower, respectively, than of the mean winter season NAO index, covering the period November to March, over the entire period from 1950-1951 to 2009-2010. Each winter month from November to March was binned into one of the 3 NAO phases based on the mean NAO value for the month in question and its deviation from the mean winter season value. Each season was also binned into one of the 3 NAO phases based on the mean NAO value for the 3 mo period from January to March and its deviation from the mean winter season value. The total number of months and January to March seasons that were classified in each NAO phase is shown in Table 1.

\subsection{Simulation of winter wheat hardening and risk of frost injury}

\subsubsection{Description of the frost tolerance model}

The FROSTOL model (Bergjord et al. 2008) was used here to simulate the effect of NAO on cold hardening and the risk of frost injury in winter wheat. This model simulates the hardening and de-hardening of winter wheat and expresses the wheat frost tolerance by the LT50. The ability of the FROSTOL model to simulate winter wheat injury due to low temperatures has previously been evaluated for conditions which represent northern Europe (Bergjord et al. 2010). The simulation with FROSTOL starts at planting and continues until the end of the winter season. Input variables for the FROSTOL model include the soil surface temperature $\left({ }^{\circ} \mathrm{C}\right)$ and the snow cover depth $(\mathrm{cm})$. The daily change $\left({ }^{\circ} \mathrm{C} \mathrm{d}^{-1}\right)$ in LT50 as a function of soil temperature and snow cover is expressed by the following equation:

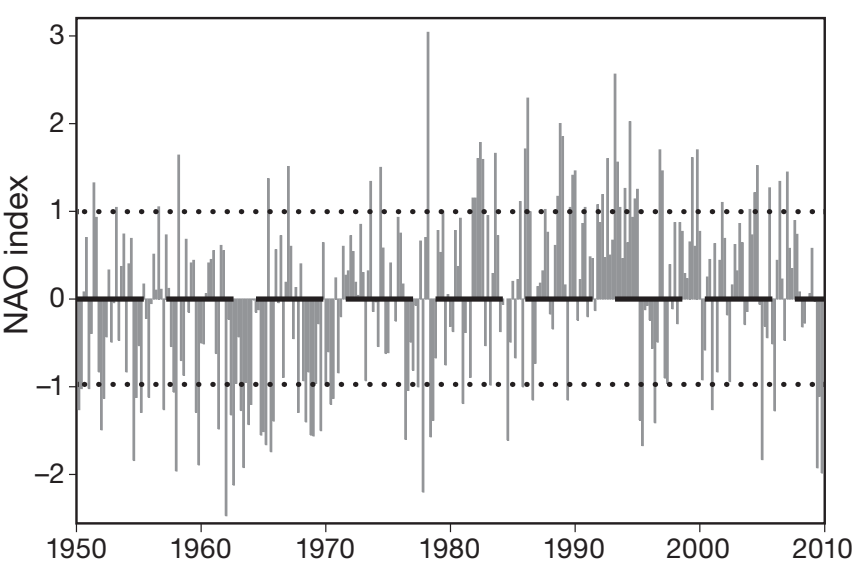

Fig. 1. Monthly mean North Atlantic Oscillation (NAO) indices during the winter period (November to March) for the seasons 1950-1951 to 2009-2010 (bars), showing the historical mean (long dashed line) and standard deviation (dotted lines)

Table 1. Number of winter months and seasons classified in each North Atlantic Oscillation (NAO) phase for the time period 1950-1951 to 2009-2010

\begin{tabular}{|lccc|}
\hline & \multicolumn{3}{c|}{ NAO } \\
\cline { 2 - 4 } & Negative & Neutral & Positive \\
\hline November & 6 & 47 & 7 \\
December & 13 & 36 & 11 \\
January & 11 & 37 & 12 \\
February & 12 & 39 & 9 \\
March & 12 & 38 & 10 \\
January to March & 8 & 48 & 4 \\
\hline
\end{tabular}

$\mathrm{LT}_{50}=\mathrm{LT}_{t} 0_{t-1}-\mathrm{RATEH}+\mathrm{RATED}+\mathrm{RATES}+$ RATER

where $\operatorname{LT} 50_{t}\left({ }^{\circ} \mathrm{C}\right)$ is the frost tolerance temperature at time $t$, RATEH defines the increase in frost tolerance by hardening, RATED represents the decrease in frost tolerance by de-hardening, and RATER and RATES are 2 stress terms. The increase in frost tolerance defined by RATEH occurs at soil surface temperatures $<10^{\circ} \mathrm{C}$. The RATEH and RATED terms in Eq. (1) are both dependent on the minimum temperature that the winter wheat frost tolerance can reach $($ LT50 $\min )$, which varies between cultivars. The hardening and de-hardening processes are also dependent on the vernalisation of the winter wheat plants. Vernalisation is a cumulative process induced by low temperatures that has an effect on the phenological development of the wheat plants. In a review on temperature effects in wheat, Porter \& Gawith (1999) reported minimum, optimum and maximum temper- 
atures for vernalisation of $-1.3,4.9$, and $15.7^{\circ} \mathrm{C}$, respectively. Higher or lower soil surface temperatures than the vernalisation optimum result in a slower vernalisation rate. For plants that are not fully vernalised, de-hardening starts at temperatures $>10^{\circ} \mathrm{C}$, while for fully vernalised plants the de-hardening temperature threshold is $-4^{\circ} \mathrm{C}$. Below these thresholds, de-hardening is not possible. After completion of vernalisation, the wheat plants lose their ability to re-harden after a de-hardening period. Stress factors affecting winter survival are taken into account by the RATES and RATER terms in Eq. (1). RATES describes the decrease in frost tolerance when the wheat plants are exposed to a prolonged period of low temperatures near the prevailing LT50 temperature $\left(\mathrm{LT} 50_{t}\right)$, while RATER is a term expressing the loss of frost tolerance due to respiration under snow cover. For a more detailed description of the FROSTOL model, see Bergjord et al. (2008).

\subsubsection{Model application}

Here we simulated the frost tolerance for 2 generic winter wheat cultivars with $\mathrm{LT} 50_{\min }$ of $-12^{\circ} \mathrm{C}$ and $-16^{\circ} \mathrm{C}$, respectively. These 2 frost tolerance types represent a number of commonly grown winter wheat cultivars in northern Europe (Bergjord et al. 2010). Three geographical locations in Norway were included in the simulations: Apelsvoll, Oppland County $\left(60^{\circ} 42^{\prime} \mathrm{N}, 10^{\circ} 52^{\prime} \mathrm{E}\right) ;$ Ås, Akershus County $\left(59^{\circ} 40^{\prime} \mathrm{N}, 10^{\circ} 48^{\prime} \mathrm{E}\right)$; and Kvithamar, Nord-Trøndelag County $\left(63^{\circ} 29^{\prime} \mathrm{N}, 10^{\circ} 52^{\prime} \mathrm{E}\right)$ (Fig. 2). These locations represent important wheat production regions with different climate conditions. For all 3 locations, simulations were performed for 53 winter seasons from 1957-1958 to 2009-2010 using observed weather data. Three fixed planting dates were used for all growing seasons: August 20, September 5 and September 20, which represent the normal variation in planting for winter wheat in Norway.

Soil surface temperature and snow cover depth, which are required input variables to the FROSTOL model, were not directly available for the 3 locations used in this study, so we calculated these weather variables using the SnowFrostIce model (Thorsen et al. 2010). This model has previously been applied to estimate the snow cover and soil surface temperatures in winter hardening studies of perennial forage grasses under similar climate conditions to those in this study (Thorsen \& Höglind 2010). Locationspecific parameters in the SnowFrostIce model have also been calibrated for several locations in Norway,

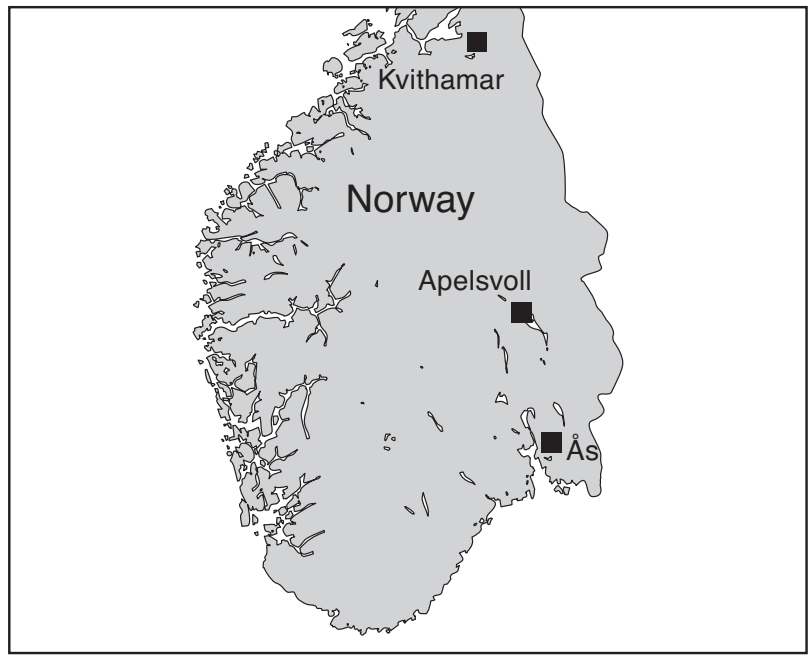

Fig. 2. Locations in Norway for which simulations were performed: Apelsvoll, Oppland County; Ås, Akershus County; and Kvithamar, Nord-Trøndelag County

including Kvithamar and Kise, Hedmark County $\left(60^{\circ} 77^{\prime} \mathrm{N}, 10^{\circ} 8^{\prime} \mathrm{E}\right)$ (Thorsen et al. 2010). The latter location has similar soil properties to Ås and Apelsvoll and was considered representative of these 2 locations. Driving variables for the SnowFrostIce model are daily minimum and maximum air temperature (Tmin and Tmax, respectively) and daily precipitation. These weather data for the 3 locations were obtained from the eKlima database of the Norwegian Meteorological Institute (http://eklima.met.no/). The temperature and precipitation datasets included a few gaps, so data for the days with missing values were generated using the Weatherman tool in the Decision Support Systems for Agrotechnology Transfer (DSSAT), version 4.0 (Hoogenboom et al. 2004). In addition to weather input data, the SnowFrostIce model requires site-specific soil physical data, which are used for calculations of soil water retention. For Apelsvoll, these data were taken from Colleuille et al. (2007), for Kvithamar from Øverlie et al. (2006), and for Ås from Riley (1993). Finally, we determined the number of frost injury events per month or season, defined as days with daily minimum soil surface temperatures below LT50 ${ }_{t}$.

\subsection{Statistical analysis}

To determine differences in the number of events with soil surface temperatures below LT50 among monthly mean NAO phases, analysis of variance (ANOVA) and least significant difference (LSD) were 
performed using PROC GLM in SAS (SAS 2008). One analysis was conducted for each of the months from November to March, as well as the January to March seasonal mean NAO phase. The analyses included the growing seasons from 1957-1958 to 2009-2010, with each growing season considered a replicate. All 3 locations and planting dates were first analysed together and possible interactions between NAO phases and locations, and between NAO phases and planting dates, were evaluated. The different locations and planting dates were then evaluated separately. Since the number of frost events was not normally distributed, the ANOVA results were compared with those from a Kruskal-Wallis test performed using the non-parametric PROC NPAR1WAY in SAS (SAS 2008). To determine whether there were any differences in the inter-seasonal distribution of frost kill events between NAO phases, we assessed statistically significant differences in the percentage of years that included one or more events of soil surface temperatures below the LT50 temperature between monthly and seasonal January to March mean NAO phases. The same statistical methods as in the first analysis were applied, and planting dates and locations were considered replicates.

\section{RESULTS}

Tmin and Tmax, as well as the accumulated precipitation during the January to March period, were averaged within each NAO phase. At all 3 locations, Tmin and Tmax, and the accumulated precipitation were lower in negative NAO phases than in neutral NAO and positive phases. Positive NAO phases corresponded to higher Tmax and Tmin than neutral NAO conditions at all 3 locations, and higher accumulated precipitation from January to March at Apelsvoll and Kvithamar (Table 2).

Assessment of winter wheat mortality risk from frost injury revealed an overall tendency for a higher number of frost injury events per season under negative NAO phases than under positive and neutral phases for both the LT $50_{\min }-12^{\circ} \mathrm{C}$ and $-16^{\circ} \mathrm{C}$ wheat frost tolerance types (Table 3 ). These NAO effects on the number of frost injury events were found when NAO phases were divided into monthly and seasonal means and with both the ANOVA and the KruskalWallis analyses $(p<0.05)$. In addition, the ANOVA analysis showed an interaction between the number of frost injury events in an NAO phase and location ( $p$ $<0.05)$. Overall, there were more frost injury events per season at Apelsvoll and Ås than at Kvithamar for
Table 2. Mean maximum and minimum air temperature (Tmax and Tmin, respectively) and accumulated precipitation in mean January to March North Atlantic Oscillation (NAO) phases at 3 locations in Norway (see Fig. 2); 1958-2010

\begin{tabular}{|lccc|}
\hline $\begin{array}{l}\text { Seasonal } \\
\text { NAO } \\
\text { phase }\end{array}$ & $\begin{array}{c}\text { Tmax } \\
\left({ }^{\circ} \mathrm{C}\right)\end{array}$ & $\begin{array}{c}\text { Tmin } \\
\left({ }^{\circ} \mathrm{C}\right)\end{array}$ & $\begin{array}{c}\text { Accumulated } \\
\text { precipitation } \\
(\mathrm{mm})\end{array}$ \\
\hline $\begin{array}{l}\text { Apelsvoll } \\
\text { Negative }\end{array}$ & -3.1 & -10.5 & 80.3 \\
Neutral & -1.7 & -8.7 & 113 \\
Positive & -0.7 & -5.6 & 123 \\
Ås & & & \\
Negative & -0.9 & -9.3 & 76.8 \\
Neutral & 0.3 & -6.9 & 131 \\
Positive & 0.4 & -6.3 & 122 \\
Kvithamar & & & \\
Negative & 0.4 & -7.0 & 164 \\
Neutral & 2.0 & -4.6 & 175 \\
Positive & 5.0 & -1.1 & 257 \\
\hline
\end{tabular}

Table 3. Mean number of frost injury events in 2 winter wheat frost tolerance types $\left(\mathrm{LT} 50_{\min }-12^{\circ} \mathrm{C}\right.$ and $-16^{\circ} \mathrm{C}$ ) for mean January to March North Atlantic Oscillation (NAO) phases at 3 locations. Values with the same letters within columns and wheat types are not significantly different $(p<0.05)$

\begin{tabular}{|lccc|}
\hline $\begin{array}{l}\text { Seasonal NAO } \\
\text { phase }\end{array}$ & Apelsvoll & Ås & Kvithamar \\
\hline $\mathbf{L T 5 0}_{\text {min }} \mathbf{- 1 2} \mathbf{1}^{\mathbf{C}}$ & & & \\
Negative & $11.8^{\mathrm{a}}$ & $12.4^{\mathrm{a}}$ & $0.81^{\mathrm{a}}$ \\
Neutral & $2.10^{\mathrm{b}}$ & $5.90^{\mathrm{b}}$ & $0.35^{\mathrm{a}}$ \\
Positive & $0^{\mathrm{b}}$ & $3.92^{\mathrm{b}}$ & $0.25^{\mathrm{a}}$ \\
$\mathbf{L T 5 0}_{\text {min }} \mathbf{- 1 \mathbf { 1 6 } ^ { \circ } \mathbf { C }}$ & & & \\
Negative & $5.76^{\mathrm{a}}$ & $5.33^{\mathrm{a}}$ & $0.19^{\mathrm{a}}$ \\
Neutral & $0.49^{\mathrm{b}}$ & $2.14^{\mathrm{b}}$ & $0.083^{\mathrm{a}}$ \\
Positive & $0.0^{\mathrm{b}}$ & $1.83^{\mathrm{b}}$ & $0.079^{\mathrm{a}}$ \\
\hline
\end{tabular}

both monthly and seasonal January to March means in all 3 NAO phases. The difference in mean number of frost injury events among NAO phases was also larger for the $\mathrm{LT} 50_{\min }-12^{\circ} \mathrm{C}$ frost tolerance wheat type than for the LT50 $0_{\min }-16^{\circ} \mathrm{C}$ type (Table 3 ).

The number of frost injury events in each monthly NAO phase is presented separately for the 3 locations and 2 wheat frost tolerance types in Fig. 3. The higher risk of a frost injury event during a negative NAO phase was clearer for February and March monthly NAO indices than for the other monthly indices. In fact, for November, December and Janu- 

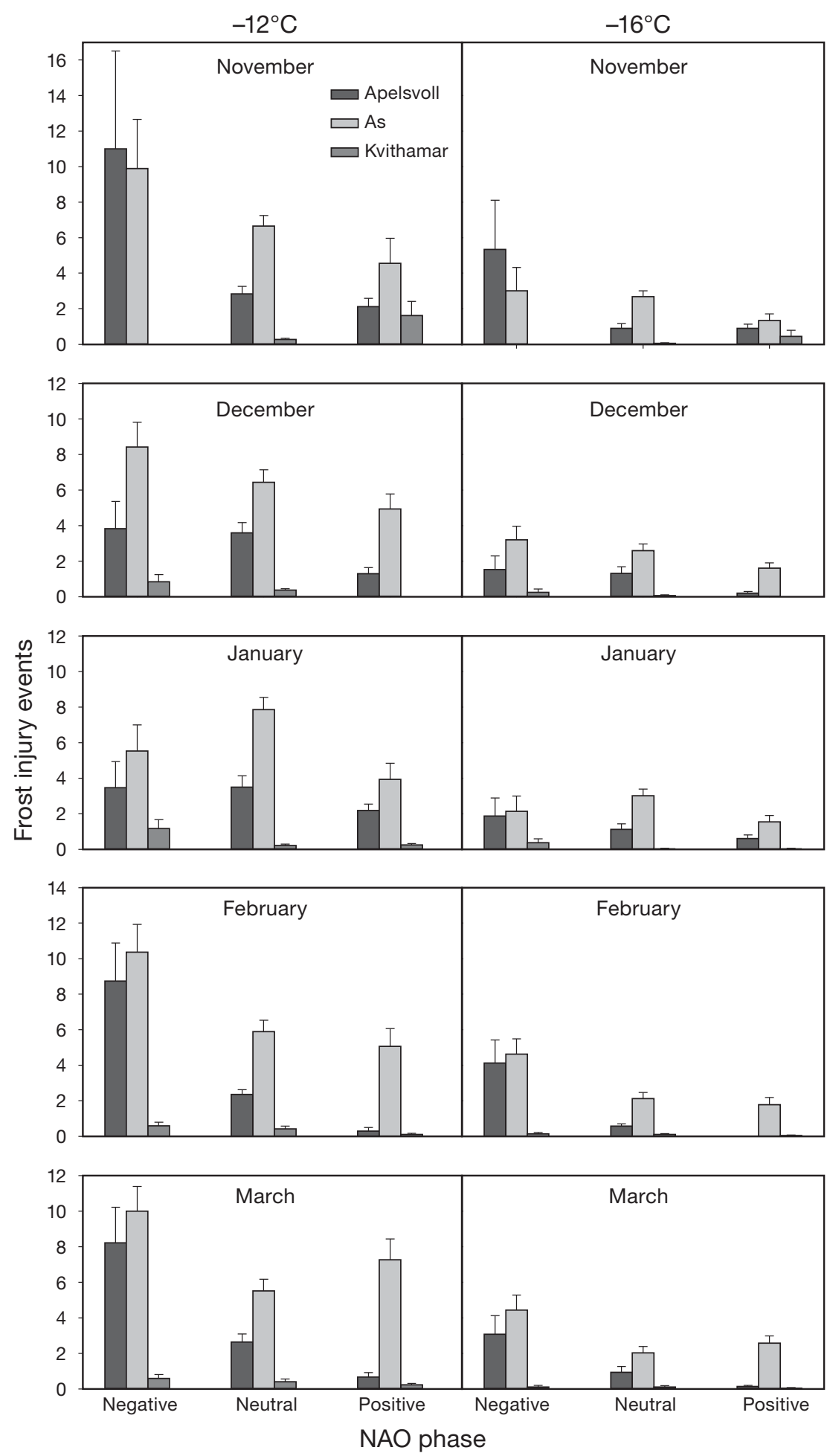

Fig. 3. Mean number (+1 SE) of frost injury events (days with minimum soil surface temperatures below LT50) per season, for monthly mean NAO phases from November to March, and for 3 locations and 2 wheat frost-tolerance types: LT $50_{\min }-12^{\circ} \mathrm{C}$ (left) and $-16^{\circ} \mathrm{C}$ (right)

ary NAO indices, there were examples of higher numbers of frost injury events under positive and neutral phases than under negative NAO phases for single locations. Similar to the January to March mean NAO index, for all individual monthly NAO indices the difference in the mean number of frost injury events among NAO phases was also larger for the LT50 $0_{\min }-12^{\circ} \mathrm{C}$ frost tolerance wheat type than for the $\mathrm{LT} 50_{\min }-16^{\circ} \mathrm{C}$ type. The NAO effect on the number of frost injury events per season also differed between planting dates (Fig. 4). For both wheat frost tolerance types, all months and all 3 NAO phases, the earlier the planting date, the higher the mean number of frost injury events per season. This tendency for a higher number of frost injury events per season after the earliest planting date was slightly more noticeable for negative NAO phases than for neutral and positive NAO phases (Fig. 4; Table 4). However, the interaction between NAO phase and planting date was not statistically significant for any of the monthly or seasonal NAO phases at any of the 3 locations.

The significantly higher number of frost injury events during negative NAO phases clearly illustrates the effect of NAO on the risk of winter frost kill. Analysis of the percentage of seasons with occurrence of one or more frost injury event gave information about how the risk of frost injury was distributed among winter seasons characterised by different NAO patterns. In summary, this analysis showed that the percentage of seasons which included at least one frost injury event was $52 \%$ for the $\mathrm{LT} 50_{\min }-12^{\circ} \mathrm{C}$ frost tolerance type and $31 \%$ for the $\mathrm{LT} 50_{\min }-16^{\circ} \mathrm{C}$ type, on average across all NAO phases, locations and planting dates. As regards the January to March seasonal NAO mean, there was a significantly higher percentage of years with frost injury events in negative NAO phases than in neutral and positive NAO phases for both wheat frost tolerance types. For the LT50 ${ }_{\min }-12^{\circ} \mathrm{C}$ frost tolerance type, there was also a 

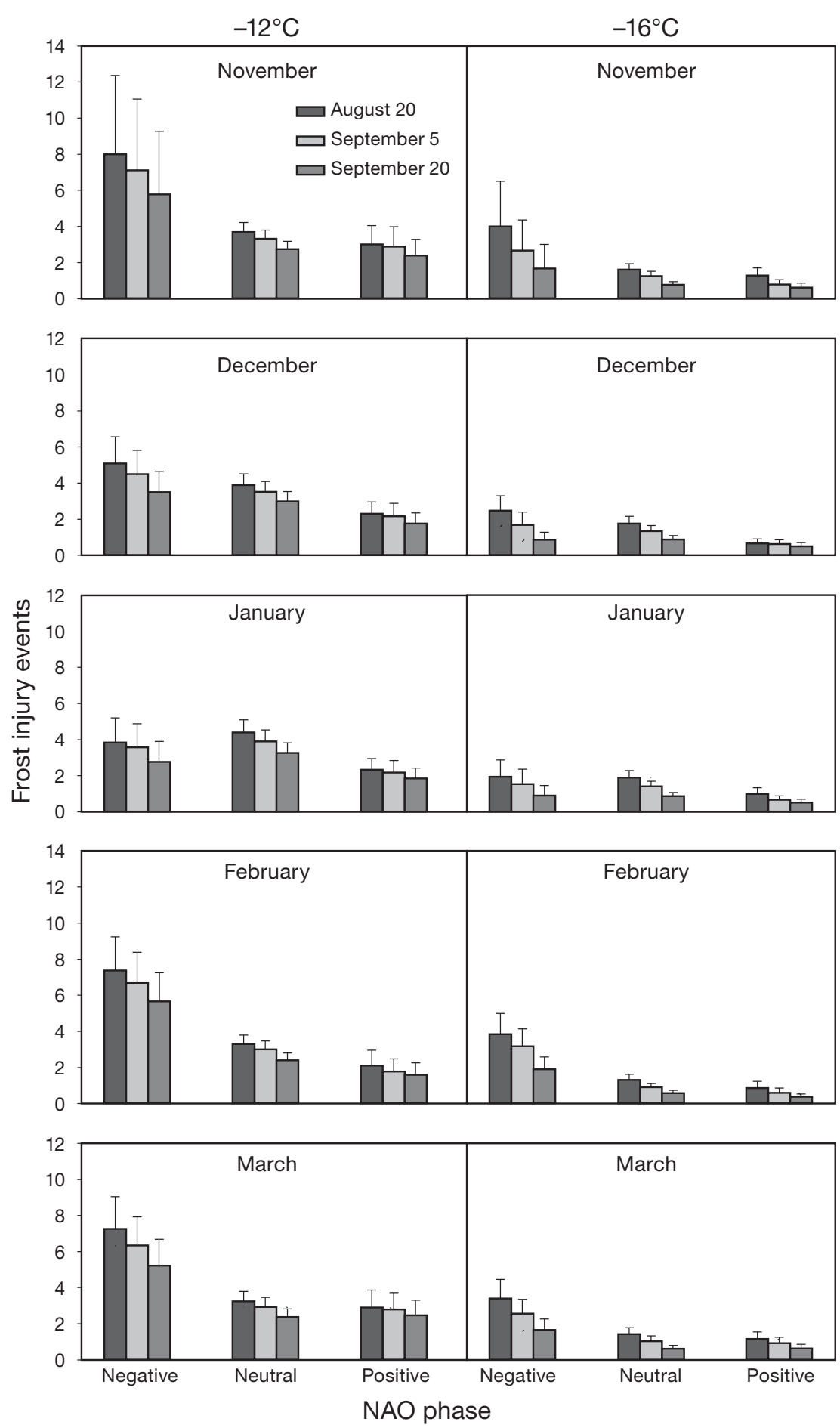

Fig. 4. Mean number (+1 SE) of frost injury events (days with minimum soil surface temperatures below LT50) per season, for monthly mean NAO phases from November to March, and for 3 different planting dates and 2 wheat frost tolerance types $\left(\mathrm{LT} 50_{\min }-12^{\circ} \mathrm{C}\right.$, left, and $-16^{\circ} \mathrm{C}$, right)
Analysis of the percentage of seasons involving at least one frost injury event, conducted separately for all monthly mean NAO phases, showed a similar pattern of NAO effect as the analysis of the number of frost injury events per season. The percentage of years with at least one frost injury event was highest when the NAO was in the negative phase late during the winter season. For the $\mathrm{LT} 50_{\min }-12{ }^{\circ} \mathrm{C}$ wheat frost tolerance type, negative March NAO phases resulted in the highest percentage $(65 \%)$ of years with frost injury events of all monthly NAO means, across locations and planting dates. The lowest percentage $(32 \%)$ of years with frost injury events occurred in positive February NAO phases. For the LT50 ${ }_{\min }-16^{\circ} \mathrm{C}$ wheat frost tolerance type, the highest percentage $(47 \%)$ of years with frost injury events occurred in seasons with negative March NAO phases and the lowest $(19 \%)$ in negative January NAO phases (Fig. 4). The percentages of seasons with at least one frost injury event in the $\mathrm{LT} 50_{\min }-12^{\circ} \mathrm{C}$ frost tolerance type were significantly different $(\mathrm{p}<0.05)$ between all March NAO phases and significantly lower $(p<0.05)$ in the positive NAO December and February phases than in the negative and neutral phases for the same months. For the $\mathrm{LT} 50_{\min }-16^{\circ} \mathrm{C}$ frost tolerance type, negative NAO phases in December, February and March resulted in significantly $(\mathrm{p}<0.05)$ higher percentage of seasons with at least one frost injury event than positive and neutral phases. However, for the same frost tolerance type in January, neutral NAO resulted in a significantly $(\mathrm{p}<0.05)$ higher percentage of seasons with at least one frost injury event than negative NAO. The percentage of significantly higher percentage of years with frost injury events in neutral NAO phases than in positive NAO phases (Table 5). seasons with at least one frost injury event was not significantly different between other monthly NAO phases (Fig. 5). 
Table 4. Mean number of frost injury events for 2 wheat frost tolerance types $\left(\mathrm{LT} 50_{\min }-12^{\circ} \mathrm{C}\right.$ and $-16^{\circ} \mathrm{C}$ ) and 3 planting dates for January to March seasonal North Atlantic Oscillation (NAO) phases. Values with the same letters within columns and cultivar types are not significantly different $(p<0.05)$

\begin{tabular}{|lccc|}
\hline $\begin{array}{l}\text { Seasonal } \\
\text { NAO phase }\end{array}$ & August 20 & September 5 & September 20 \\
\hline LT50 $_{\text {min }} \mathbf{- 1 2} \mathbf{~}^{\circ} \mathbf{C}$ & & & \\
Negative & $9.33^{\mathrm{a}}$ & $8.29^{\mathrm{a}}$ & $7.33^{\mathrm{a}}$ \\
Neutral & $3.18^{\mathrm{b}}$ & $2.88^{\mathrm{b}}$ & $2.28^{\mathrm{b}}$ \\
Positive & $1.42^{\mathrm{b}}$ & $1.42^{\mathrm{b}}$ & $1.33^{\mathrm{b}}$ \\
LT50 $_{\text {min }} \mathbf{- 1 \mathbf { 1 6 } ^ { \circ } \mathbf { C }}$ & & & \\
Negative & $4.76^{\mathrm{a}}$ & $3.95^{\mathrm{a}}$ & $2.57^{\mathrm{a}}$ \\
Neutral & $1.28^{\mathrm{b}}$ & $0.90^{\mathrm{b}}$ & $0.54^{\mathrm{b}}$ \\
Positive & $0.92^{\mathrm{b}}$ & $0.58^{\mathrm{b}}$ & $0.42^{\mathrm{b}}$ \\
\hline
\end{tabular}

Table 5. Proportion of years (\%) with one or more frost injury event for different January to March seasonal North Atlantic Oscillation (NAO) phases and 2 wheat frost-tolerance types $\left(\mathrm{LT} 50_{\min }-12^{\circ} \mathrm{C}\right.$ and $-16^{\circ} \mathrm{C}$ ). Values with the same letters within columns and wheat types are not significantly different $(p<0.05)$

\begin{tabular}{|lcc|}
\hline Seasonal NAO phase & LT50 $_{\text {min }}-12^{\circ} \mathrm{C}$ & LT50 $_{\text {min }}-16^{\circ} \mathrm{C}$ \\
\hline Negative & $61.9^{\mathrm{a}}$ & $46.0^{\mathrm{a}}$ \\
Neutral & $52.9^{\mathrm{a}}$ & $29.9^{\mathrm{b}}$ \\
Positive & $25.0^{\mathrm{b}}$ & $19.4^{\mathrm{c}}$ \\
\hline
\end{tabular}

\section{DISCUSSION}

Our findings on the effects of the NAO on levels of frost injury in winter wheat provide an important example of how climate variability can affect field crop production. This study determined the specific effect of NAO variation during the winter season on winter wheat production security for locations in Norway, which are also representative of winter wheat production regions in other countries in northwestern Europe. The NAO-induced climate effects include higher precipitation rates and higher mean air temperatures during positive NAO phases than during negative and neutral phases (Hurrell et al. 2003), which was also the case at the specific locations that were included in this study. These conditions affect both hardening in autumn and frost exposure during the winter. The NAO effect on frost tolerance and winter survival presented in this study may, with this background information, not seem very surprising. However, frost injury events are not necessarily linearly related to the precipitation and the mean air temperature. Instead the frost injury events are determined by the mutual interactions

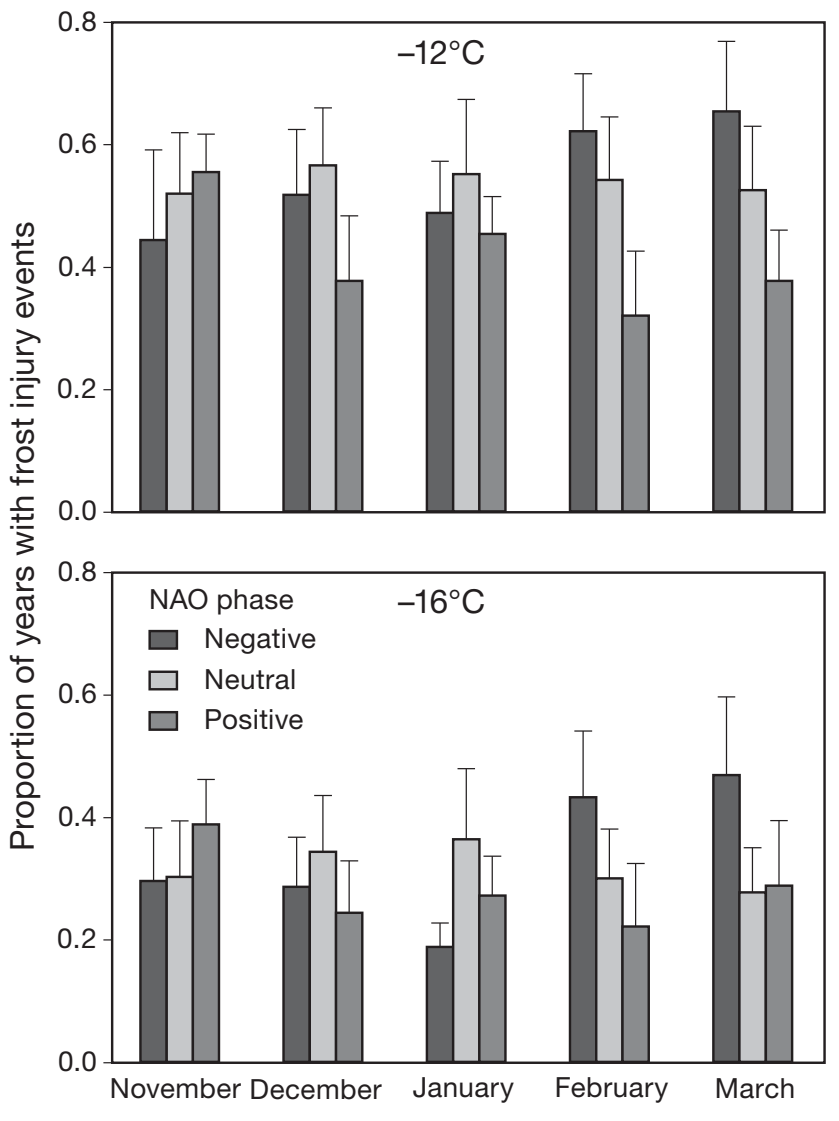

Fig. 5. Relative number of years (+1 SE) with one or more frost injury event (a day with minimum soil surface temperatures below LT50) for North Atlantic Oscillation (NAO) phases during November to March and 2 wheat frost-tolerance types (LT50 min $-12^{\circ} \mathrm{C}$ and $-16^{\circ} \mathrm{C}$ ), based on combined data across 3 locations and 3 planting dates

between precipitation and mean air temperature as well as to their interaction with cold extreme events and wheat plant development. The use of a processbased crop model for frost tolerance and winter injury in this study made it possible to analyse these non-linear relationships, which cannot be deduced from by studying of the effect of NAO on mean air temperature and precipitation alone.

The clearest specific result of this study is arguably the higher number of frost injury events in winter wheat occurring during seasons when the NAO is in a negative phase in February and March than when it is in a positive or neutral phase. Another important result is the higher risk of frost injury after early planting in late August than after planting in midSeptember. These results confirm findings of other studies that analysed the effect of planting date on winter injury of wheat without regard to the possible influence of NAO (Andrews et al. 1997). 
The higher risk of frost injury after early planting was linked to the vernalisation process and its effect on plant hardening and de-hardening, as early planting results in longer exposure to temperatures within the range of vernalisation induction and consequently also in earlier completion of vernalisation (data not shown). This in turn leads to an earlier decrease in frost tolerance late in the winter season due to an earlier onset of the de-hardening, which explains why the NAO effects were largest for the February and March indices. However, there was no significant interaction between NAO phase and planting date on the one hand and the number of frost injury events on the other, suggesting that NAO may have an effect on the risk of frost kill regardless of planting date within its normal regional time frame from late August to mid-September.

Another finding of this study with possible practical consequences for winter wheat production is the variation in NAO effect between sites. In recent decades, the majority of winter wheat in Norway has been produced in southeastern regions of the country, including Akershus, Oppland and neighbouring counties (Rognstad \& Steinset 2010). The relatively lower overall risk of frost kill and smaller effects of NAO-related frost kill at Kvithamar in central Norway suggest that having an increased proportion of winter wheat production in this region could decrease the exposure of winter wheat to NAO-related frost kill. However, in order to fully analyse the implications of changes in the production centre of winter wheat, other factors that affect yield levels, e.g. ice encasement (Hakala et al. 2011) and fungal infections (Iriki et al. 2001, Matsumoto 2009), should be taken into account. However, little is known about the potential dependence of other winter stress factors on NAO. In particular, knowledge about potential relationships between NAO and fungal infections in wheat during the winter period could further contribute to understanding of winter production security in different regions under a variety of climate conditions. In fact, for Finnish conditions it was concluded that breeding for snow conditions, including selection of plants with enhanced resistance to low temperature fungi, was an important factor leading to increased winter survival of wheat (Linden et al. 1999). Comparisons of the results from this study with field observations indicate that factors other than low temperature stress also contribute to total winter wheat kill under Norwegian conditions. Observations of winter wheat survival from the last $15 \mathrm{yr}$ in Apelsvoll and Ås (unpublished data) showed, in many cases, a higher winter kill than could be expected from low temperature stress alone. Other factors, such as planting date and the inclusion of winter wheat cultivars with LT50 min values that differ from those included in this study, further complicate the validation of our results against field data. Unfortunately, cultivars are not regularly tested for LT50 min in the Norwegian cultivar testing program for wheat.

The validation study of FROSTOL using field data from Finland (Bergjord et al. 2010) indicated that often more than one simulated frost event was necessary to reduce the plant density by $50 \%$, suggesting that $\mathrm{LT} 50_{\text {min }}$ might underestimate the plants' ability to withstand frost exposure in the field. These results suggest that more research is needed to determine the relationship between frost tolerance in standard freezing test and in the field. Nevertheless, knowledge about the effect of frost stress alone on winter survival of wheat, and about the underlying mechanisms involved, aid the understanding of frost winter kill.

The results presented here add to the general knowledge about NAO and its effect on field crop production. Previous studies demonstrated an effect of NAO on wheat yield quality (Atkinson et al. 2008) and quantity (Cantelaube et al. 2004). In contrast to those studies, which were based on statistical means of historical yields, we applied a dynamic simulation model to mechanistically account for temperature, precipitation and snow cover related effects of NAO. This approach makes it possible to identify and thus understand the causal relationship between climatic factors that are affected by NAO and frost kill of winter wheat. Another advantage of applying a mechanistic model instead of using historical information from statistical databases is the possibility of conducting analyses of conditions for which field data are scarce and insufficient, for example over long time periods and under different management practices as in this study, or under scenarios for the future, e.g. climate change projections. Currently interannual NAO variability cannot be predicted with very high accuracy (Bojariu \& Gimeno 2003, Cohen \& Fletcher 2007). Nevertheless, advancement in NAO prediction methods could allow our methods to be used in winter wheat production planning for regions where the winter climate is affected by the NAO. For example, in years where NAO predictions indicate severe risk of winter kill, the farmer could plant spring wheat instead of winter wheat.

Another arguably easier method to decrease the winter kill risks in wheat due to NAO related climate variability would be to plant the most winter hardy variety available. However, winter hardy wheat cul- 
tivars are often disadvantageous compared to less hardy cultivars as regards other agronomic factors such as grain yield (Saulescu \& Braun 2001). Adaptation of winter wheat cultvation according to NAO predictions would allow selection of wheat varieties that are more advantageous - in terms of yield and other aspects - for the prevailing winter conditions.

In conclusion, this study showed a significant effect of NAO on the risk of frost injury events and thus also the risk of winter kill of wheat in a region representative of the northern European climate. A logical next step would be to link the FROSTOL model to a simulation model for winter wheat growth and grain yield in order to determine the total effect of NAO during the entire growing season on winter wheat yields. Further studies of the NAO effect on winter wheat production could also be applied to other important production regions exposed to severe winter climate, e.g. in other parts of Europe or North America, to obtain more knowledge from a global perspective.

Acknowledgements. We thank Dr. Hans Martin Hanslin, Norwegian Institute for Agricultural and Environmental Research, Særheim, for help with the statistical analyses. This study was conducted with financial support from the Norwegian Ministry of Agriculture and Food.

\section{LITERATURE CITED}

- Alexandrov VA, Hoogenboom G (2001) Climate variation and crop production in Georgia, USA, during the twentieth century. Clim Res 17:33-43

Andrews CJ, Pomeroy MK, Seaman WL, Butler G, Bonn PC, Hoekstra G (1997) Relationships between planting date, winter survival and stress tolerances of soft white winter wheat in eastern Ontario. Can J Plant Sci 77:507-513

> Atkinson MD, Kettlewell PS, Hollins PD, Stephenson DB, Hardwick NV (2005) Summer climate mediates UK wheat quality response to winter North Atlantic Oscillation. Agric Meteorol 130:27-37

> Atkinson MD, Kettlewell PS, Poulton PR, Hollins PD (2008) Grain quality in the Broadbalk Wheat Experiment and the winter North Atlantic Oscillation. J Agric Sci 146: 541-549

- Bergjord AK, Bonesmo H, Skjelvag AO (2008) Modelling the course of frost tolerance in winter wheat. I. Model development. Eur J Agron 28:321-330

> Bergjord AK, Bonesmo H, Skjelvag AO (2010) Model prediction of frost tolerance as related to winter survival of wheat in Finnish field trials. Agr Food Sci 19:184-192

- Bojariu R, Gimeno L (2003) Predictability and numerical modelling of the North Atlantic Oscillation. Earth Sci Rev 63:145-168

> Cantelaube P, Terres JM, Doblas-Reyes FJ (2004) Influence of climate variability on European agriculture-analysis of winter wheat production. Clim Res 27:135-144

> Cohen J, Fletcher C (2007) Improved skill of northern hemisphere winter surface temperature predictions based on land-atmosphere fall anomalies. J Clim 20:4118-4132
Colleuille H, Haugen LE, Øverlie T (2007) Vann i jord: simulering av vann- og energibalansen på Kise markvannstasjon, Hedmark. Norges vassdrags og energidirektorat, Oslo

> Dickson RR, Osborn TJ, Hurrell JW, Meincke J and others (2000) The Arctic Ocean response to the North Atlantic Oscillation. J Clim 13:2671-2696

Fischer EM, Luterbacher J, Zorita E, Tett SFB, Casty C, Wanner H (2007) European climate response to tropical volcanic eruptions over the last half millennium. Geophys Res Lett 34:L05707 doi:10.1029/2006GL027992

> Fowler DB, Limin AE, Ritchie JT (1999) Low-temperature tolerance in cereals: model and genetic interpretation. Crop Sci 39:626-633

> Gimeno L, Ribera P, Iglesias R, de la Torre L, Garcia R, Hernandez E (2002) Identification of empirical relationships between indices of ENSO and NAO and agricultural yields in Spain. Clim Res 21:165-172

Hansen-Bauer I, Førland EJ, Roald L, Hisdal H and others (2009) Klima i Norge 2100 Begrunnsmateriale til NOU Klimatilpasning. Norsk klimasenter, Bergen

> Hakala K, Hannukkala AO, Huusela-Veistola E, Jalli M, Peltonen-Sainio P (2011) Pests and diseases in a changing climate: a major challenge for Finnish crop production. Agr Food Sci 20:3-14

Hoogenboom G, Jones JW, Wilkens PW, Porter CH and others (2004) Decision support systems for agrotechnology transfer, version 4. CD-ROM. University of Hawaii, Honolulu

Hsieh WW, Tang BY, Garnett ER (1999) Teleconnections between Pacific sea surface temperatures and Canadian prairie wheat yield. Agric Meteorol 96:209-217

Hurrell JW, Kushnir Y, Ottersen G, Visbeck M (eds) (2003) An overview of the North Atlantic Oscillation. In: The North Atlantic Oscillation: climatic significance and environmental impact. American Geophysical Union, Washington, DC, p 7-36

Iriki N, Kawakami A, Takata K, Kuwabara T, Ban T (2001) Screening relatives of wheat for snow mold resistance and freezing tolerance. Euphytica 122:335-341

> Izaurralde RC, Rosenberg NJ, Brown RA, Legler DM, Lopez MT, Srinivasan R (1999) Modeled effects of moderate and strong 'Los Niños' on crop productivity in North America. Agric Meteorol 94:259-268

Linden L, Palonen P, Seppanen M (1999) Cold hardiness research on agricultural and horticultural crops in Finland. Agr Food Sci 8:459-477

Lopez-Moreno JI, Vicente-Serrano SM (2008) Positive and negative phases of the wintertime North Atlantic Oscillation and drought occurrence over Europe: a multitemporal-scale approach. J Clim 21:1220-1243

Matilda Agricultural Statistics (2012) Estimated area sown to winter crops. Information Centre of the Ministry of Agriculture and Forestry, Helsinki. www.maataloustilastot.fi/ en/estimated-area-sown-winter-crops-2011_en

Matsumoto N (2009) Snow molds: a group of fungi that prevail under snow. Microbes Environ 24:14-20

Øverlie T, Colleuille H, Haugen LE (2006) Vann i jord: simulering av vann- og energibalansen på Værnes markvannsstasjon, Nord-Trøndelag. Norges vassdrags- og energidirektorat, Olso

> Porter JR, Gawith M (1999) Temperature and the growth and development of wheat: a review. Eur J Agron 10: 23-36

Riley H (1993) Jordfysiske målinger på forsøksfeltene. Produksjonsmodell for eng, tilpassing til norsk klima og 
plantemateriale. Statens fagtjeneste for landbruket, Ås

Ritchie JT (1991) Wheat phasic development. In: Hanks RJ, Ritchie, JT (eds) Modeling plant and soil systems. ASACSSA-SSSA, Madison, WI

Rodriguez-Puebla C, Ayuso SM, Frias MD, Garcia-Casado LA (2007) Effects of climate variation on winter cereal production in Spain. Clim Res 34:223-232

Rodwell MJ, Folland CK (2003) Atlantic air-sea interaction and seasonal predictability. Quart J Roy Meteorol Soc 128:1413-1443

Rognstad O, Steinset TA (2010) Landbruket i Norge 2009: Jordbruk - Skogbruk - Jakt. Statistics Norway, Oslo

SAS (2008) SAS for Windows. SAS Institute, Cary, NC

Saulescu NN, Braun HJ (2001) Cold tolerance. In: Reynolds MP, Ortiz-Monasterio JI, McNab A (eds) Application of physiology in wheat breeding. International Maize and Wheat Improvement Center (CIMMYT), Mexico City

Savdie I, Whitewood R, Raddatz RL, Fowler DB (1991) Potential for winter-wheat production in western Canada: a CERES model winter risk assessment. Can J

Editorial responsibility: Tim Sparks,

Cambridge, UK
Plant Sci 71:21-30

Schmidhuber J, Tubiello FN (2007) Global food security under climate change. Proc Natl Acad Sci USA 104: 19703-19708

Skinner DZ, Mackey B (2009) Freezing tolerance of winter wheat plants frozen in saturated soil. Field Crops Res 113:335-341

Statistics Sweden (2011) Jordbruksstatistisk Årsbok 2011. Statistika Centralbyrån, Stockholm

Thorsen SM, Höglind M (2010) Assessing winter survival of forage grasses in Norway under future climate scenarios by simulating potential frost tolerance in combination with simple agroclimatic indices. Agric Meteorol 150: 1272-1282

Thorsen SM, Roer AG, van Oijen M (2010) Modelling the dynamics of snow cover, soil frost and surface ice in Norwegian grasslands. Polar Res 29:110-126

Trigo RM, Osborn TJ, Corte-Real JM (2002) The North Atlantic Oscillation influence on Europe: climate impacts and associated physical mechanisms. Clim Res 20:9-17

Submitted: September 13, 2011; Accepted: February 26, 2012 Proofs received from author(s): May 14, 2012 